\title{
腎臓への核酸導入技術の開発
}

\author{
向井英史, ${ }^{a}$ 川上＼cjkstart茂, ${ }^{a}$ 橋田 充*,a,b
}

\section{Development of Nucleic Acid Transfection Technology to the Kidney}

\author{
Hidefumi MukaI, ${ }^{a}$ Shigeru KaWAKAMI ${ }^{a}$ and Mitsuru HASHIDA ${ }^{*, a, b}$ \\ ${ }^{a}$ Graduate School of Pharmaceutical Sciences, Kyoto University, 46-29 Yoshida Shimoadachi-cho, \\ Sakyo-ku, Kyoto 606-8501, Japan, and ${ }^{b}$ Institute for Integrated Cell-Material Sciences (iCeMS), \\ Kyoto University, 69 Konoe-cho, Yoshida, Sakyo-ku, Kyoto 606-8501, Japan
}

(Received July 22, 2008)

\begin{abstract}
The kidney is one of the most important organs that play a crucial role in homeostasis and, therefore, congenital or acquired renal dysfunction causes refractory diseases, i.e., Alport's syndrome, Fabry's disease, diabetic nephropathy, IgA nephropathy, kidney cancer, transplant glomerulopathy. Nucleic acid transfection technology to the kidney is indispensable for the progress of biomedical research and the realization of gene therapy and nucleic acid drug for renal diseases. Control of renal nucleic acid transfection was difficult because of the structural complexity; however, the study of recombinant virus, synthetic carrier and physical force-mediated nucleic acid transfection to the kidney has advanced. Recombinant virus and synthetic carrier-mediated methods require long-term block of the blood or urinary flow for efficient transfection of nucleic acid because of the rich blood flow of the kidney. In contrast, physical force-mediated methods that transfect with nucleic acid via transient membrane permeability do not apprehend ischemia-reperfusion injury and, therefore, may be beneficial for nucleic acid transfection to the kidney. In this article, we collect the information of therapeutic gene, target molecule of the nucleic acid drug and target cells for renal diseases and structural property of the kidney from the point of view of nucleic acid transfection. Additively, current status of nucleic acid transfection technology to the kidney is reviewed.
\end{abstract}

Key words — transfection; kidney; gene therapy; nucleic acid drug; renal press mediated transfection method

\section{1. はじめに}

腎臓は，電解質並びに水の排泄を調節して体液の 量や組成を一定に保つと同時に，代謝により生じた 老廃物を除去し必須物質を選択的に保持する役割を 果たしており, 生体の恒常性維持に重要な臟器であ る. その先天的・後天的機能異常は, 個体の生存や quality of life（QOL）に多大な影響を与え，難治 性疾患が多く存在するため, 腎蔵は基礎医学研究, 並びに，医療において重要な対象である，代表的な 腎疾患として，アルポート症候群やファブリー症候 群等の遺伝性疾患, 糸球体が主に障害される IgA 腎症や糖尿病性腎症，また，薬物誘発性尿細管間質

a京都大学大学院薬学研究科薬品動態制御学分野 （广606-8501 京都市左京区吉田下阿達町 46-29）， $b$ 京 都大学物質-細胞統合システム拠点（iCeMS）（６0068501 京都市左京区吉田近衛町 69)

*e-mail: hashidam@pharm.kyoto-u.ac.jp 本総説は, 日本薬学会第 128 年会シンポジウム GS3 で 発表したものを中心に記述したものである.
性腎炎が挙げられ，疾患進行に伴い，線維化が進み 腎不全状態に陥ると，透析，移植治療を必要とす る. 加えて, 腎細胞がん, 移植腎拒絶等も重要であ る. ${ }^{1,2)}$

近年, 全ヒトゲノム配列情報及びマイクロアレイ 技術を基盤とした網羅的遺伝子発現解析や，高分解 能質量分析装置開発が可能にしたプロテオーム解析 により，多様な疾患に対して関連遺伝子が同定され ており, 腎疾患に関しても, 糸球体腎炎等の関連遺 伝子同定が報告され始め, ${ }^{3)}$ 今後情報の蓄積が予想 される．主に，遺伝子のタンパク質合成段階を制御 して治療効果を得る戦略である, 遺伝子治療や核酸 医薬品開発は根治療法提供に大きな可能性を秘め, 透析患者人口の増加等による医療費高騰を抑制する 社会的要請もあり, 将来の腎疾患治療において, 一 定の貢献が求められる.

核酸は負電荷を帯びたデオキシリボ核酸（DNA） やリボ核酸（RNA）であり，細胞膜透過性や標的 
指向性がそしいため，生体内での核酸導入技術が遺 伝子治療，及び核酸医薬品の実現に必須であり, ${ }^{4)}$ また，基礎医学研究の段階においても，個体レベル での遺伝子機能解析，疾患モデル構築，遺伝子治 療・核酸医薬品開発の戦略検証等において汎用され る必要不可欠な基盤技術である。腎臓の構造が, 肺，肝臓，がん組織等5,6) と比較し複雑・精緻であ るため, 腎臓への生体内核酸導入制御は困難であつ たが，リコンビナントウイルス，合成キャリア，あ るいは物理刺激を利用した導入技術に関する情報が 蓄積されつつある。

本総説では, 動態学的観点から, 遺伝子治療・核 酸医薬品開発の対象となる腎疾患の特徵，及び，腎 臓の構造について整理し，腎臓への核酸導入技術の 現状について概説する。

\section{2. 遺伝子治療や核酸医薬品開発の対象となる腎 疾患}

従来有効な治療法のない致死性疾患，あるいは QOL への影響の大きい慢性疾患等を主な対象に遺 伝子治療や核酸医薬品開発が進められている．現在 の腎疾患に対する遺伝子治療や核酸医薬品の臨床試 験は，腎がん組織への発現ベクター直接投与や，全 身に分泌されて機能するタンパク質の発現ベクター 筋肉内投与，核酸医薬品の静脈内投与をプロトコー ルとするものに限られているが, 7,8) 疾患モデル動物 を用いた評価において多様な腎疾患に対する遺伝子 治療や核酸医薬品開発戦略の有効性が証明され始め ている。ここでは，1）遺伝子発現べクター及び核 酸医薬品導入の標的細胞，2）外来遺伝子産物であ るタンパク質や核酸医薬品標的分子の動態学的特性,

3）各疾患の病態時における臓器・組織構造等を整 理する。

2-1. アルポート症候群 アルポート症候群 は，主にX 染色体上のIV型コラーゲン $\alpha_{5}$ 鎖を規定 する部分の変異や欠失に起因する, 伴性優性遺伝を 示す感音性難聴を伴う進行性腎炎の一群であり，血 尿，タンパク尿がみられ，X 染色体が 1 本しかな い男性の場合特に，腎機能が次第に低下し腎不全に 陷る，現在，腎不全への進行を阻止する治療法はな く，最終的に透析・移植療法が行われる，IV型コ ラーゲン $\alpha_{5}$ 鎖は細胞質内で合成後分泌され， $\alpha_{3}$ 鎖, $\alpha_{4}$ 鎖とトロポコラーゲンを形成し，成人の糸球体 基底膜を構成する，アルポート症候群の患者ではそ
の欠失により，糸球体基底膜の断裂・層状化がみら れる，IV型コラーゲン $\alpha_{5}$ 鎖が分泌性タンパクであ るため，発現べクターを本来の産生細胞と考えられ ている足細胞，あるいは，周囲の糸球体細胞に導入 しタンパク質を高発現，分泌させることで，症状の 改善が期待される．外来遺伝子から発現したIV型コ ラーゲン $\alpha_{5}$ 鎖が培養細胞において $\alpha_{3}, \alpha_{4}$ 鎖とトロ ポコラーゲンを形成すること，さらに，ブタを用い た検討で糸球体基底膜に分布していることが確認さ れている.9

2-2. 腎炎, 腎線維症糸球体腎炎, 並びに, 尿細管間質性腎炎は，慢性化すると次第に線維化が 進み，最終的に腎不全に陥るため透析・移植療法を 必要とし，QOL の低下を招く，糸球体腎炎は原発 性の IgA 腎症や全身疾患である糖尿病等に起因 し，尿細管間質性腎炎は，薬物誘発性，感染性等が 多い。詳細な病因や機序が解明されていない疾患も あり，炎症性サイトカイン等の産生抑制・線維化の 予防，また，一部の糸球体腎炎ではメサンギウム細 胞の増殖抑制により，腎不全状態を回避する戦略が 有力である.

転写因子 NF $\kappa \mathrm{B}$ はインターロイキン (IL) -1, IL-6, IL-8，接着分子である ICAM-1, VCAM, ELAM 等 の発現を制御しているため，炎症抑制の標的であ り，デコイ DNA 等を用い $\mathrm{NF} \kappa \mathrm{B}$ の核内移行抑制に よる炎症軽減が期待される。ただし，上記遺伝子の 発現抑制効果は核酸導入された細胞に限局されるた め, 比較的広範な細胞への導入技術が必要である。 既に，マウス TNF- $\alpha$ 誘発腎炎モデルへの NF $\kappa \mathrm{B}$ デ コイ DNA 投与による炎症性サイトカイン産生の抑 制, ${ }^{10)}$ 並びに，ラットタンパク負荷モデルへの非分 解型 $\mathrm{I} \kappa \mathrm{B} \alpha$ 発現べクター投与による接着分子産生抑 制，及び，線維化に関与する transforming growth factor (TGF) - $\beta$ やフィブロネクチンの減少が確認 されている. ${ }^{11}$

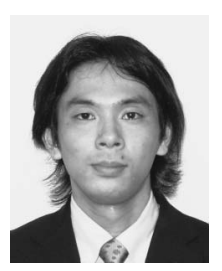

向井英史
京都大学大学院薬学研究科博士後期課 程. 1981 年大阪府茨木市生まれ。京都 大学工学部工業化学科卒業. 同大学院 工学研究科分子工学専攻修士課程修 了, 人工酵素・錯体触媒開発に携わつ た. 2006 年 4 月同大学院薬学研究科博 士後期課程に進学，橋田充教授の主宰 する薬品動態制御学分野に所属し, 核 酸 DDS 開発に従事している。 
また，腎線維化及び腎不全と関連の重要性が知ら れている hepatocyte growth factor (HGF) と TGF$\beta$ 間の均衡を改善して治療につなげる試みも行われ ている。均衡が HGF 優位な状態では代償性再生が 進み，TGF- $\beta$ 優位の持続により腎線維化及び腎不 全が引き起こされる.12) ラット抗 Thy1 抗体誘発腎 炎モデル，側輸尿管閉塞（UUO）モデル，タンパ ク負荷モデル等を用いた検討において，HGF 発現 ベクター, ${ }^{13)}$ TGF- $\beta$ シグナル伝達を抑制する分子で ある Smad7 発現べクター, ${ }^{14,15)}$ TGF- $\beta$ アンチセン スオリゴヌクレオチド投与による, ${ }^{16,17)}$ 腎線維化並 びに腎不全の抑制が報告されている。動態学的観点 から考えると, HGF や抗 TGF- $\beta$ 抗体は細胞外に分 泌され機能するため，標的である糸球体又は尿細管 周辺細胞で高発現させればよいが，一方， $\operatorname{Smad} 7$ や TGF- $\beta$ アンチセンスオリゴヌクレオチドは細胞 内で機能する分子であるため，広範な細胞への導入 が必要である.

メサンギウム細胞増殖に関連する転写因子 E2F やEgr1 の活性化抑制による糸球体腎炎治療戦略で は，ラット抗 Thyl 抗体誘発腎炎モデルに対し， E2F デコイ DNA ${ }^{18)}$ やEgr1 アンチセンスオリゴヌ クレオチド19) 投与による proliferating cell nuclear antigen (PCNA), 又は, platelet-derived growth factor-B（PDGF-B）産生抑制，さらに，メサンギウム 細胞増殖抑制が報告されている，有効な治療効果を 得るためには広範なメサンギウム細胞への導入が重 要である. 最近, 系球体腎炎組織の網羅的遺伝子発 現解析から，疾患関連遺伝子としてプロテインキ ナーゼ CK2 のサブユニット CK2 $\alpha$ が同定され，ラ ット抗 Thy1 抗体誘発腎炎モデルに対し, CK2 $\alpha$ 標 的アンチセンスオリゴヌクレオチド導入による炎症 抑制が確認され， ${ }^{3)}$ 新たな標的として期待されてい る.

2-3. 腎細胞がん＼cjkstart腎細胞がんは，尿細管上皮 細胞由来の悪性腫瘍であり, 従来の化学療法, 放射 線療法に対し耐性を示す場合が多く，新規な治療戦 略として疾患関連遺伝子や細胞内伝達経路を標的と した戦略，免疫系活性化，血管新生阻害等の戦略に 基づく遺伝子治療・核酸医薬品開発が検討されてい る。現在，免疫系活性化を目的とした IL-2, Granulocyte Macrophage colony-stimulating Factor (GM$\mathrm{CSF}$ ) 等のサイトカイン, HLA-B7/ $\beta 2$ ミクログロ
ブリンや B7-1 等の遺伝子導入による治療が, 7$)$ ま た，核酸医薬品においては，アポトーシス経路を標 的とする Bcl-2 アンチセンスオリゴヌクレオチド, 薬剤耐性に係わるリボヌクレオチド還元酵素 R2 の アンチセンスオリゴヌクレオチド，VEGF の受容 体チロシンキナーゼを標的とする抗 FLT-1 リボザ イムに関して臨床試験が行われている. ${ }^{8)}$ サイトカ イン類は分泌性タンパク質であるため，ある程度の がん細胞や周囲の正常細胞，又は，ex vivo 法によ り投与されたがん細胞において，発現，分泌すれば よい，一方，細胞表面に分布して，免疫担当細胞に 認識される HLA-B7 やB7-1，また，アンチセンス オリゴヌクレオチドやリボザイム等は細胞内で機能 する分子であり，原理的にはすべてのがん細胞への 導入が必要とされる.

また，腎細胞がん関連遺伝子として，von Hippel-Lindau（VHL）遺伝子が知られており，約 50 \%の患者において変異がみられ，約 10\%の確率で メチル化が起こっている. ${ }^{20)}$ VHL は hypoxia-inducible factor (HIF) と結合，プロテオソーム分解 を誘導する役割を担っており，その発現低下により， HIF が恒常的に活性化し，VEGF やPDGF 等の増 殖因子産生を促し，がん細胞の浸潤，転移に係わる. Lin らは，ヒト腎がん細胞移植モデルにおいて， VEGF デコイ受容体をコードした発現ベクター投 与によるリンパ節転移抑制効果を報告した。 ${ }^{21)}$ 近 年，抗 VEGF 抗体静脈内投与による臨床試験にお いて，全身性副作用が問題視されているため, 22) 腎 がん組織局所でタンパク質を産生させる代替戦略と して期待される。

2-4. その他の腎疾患ファブリー症候群は, リソソーム内糖脂質分解酵素の 1 つである $\alpha$-ガラ クトシダーゼ A の活性欠損・低下による先天性代 謝異常症であり，セラミドトリヘキソシドという糖 脂質が蓄積し，腎臓を含む多様な臟器に障害を引き 起こす。 $\alpha$-ガラクトシダーゼ $\mathrm{A}$ 遺伝子を筋肉内へ 導入し，タンパク質を全身分泌させる戦略が検討さ れた. ${ }^{7)}$ また，慢性腎疾患に伴う貧血に対しても， 赤血球産生を促進するホルモンであるエリスロポエ チンの筋肉内への遺伝子導入による臨床試験が進め られている.7)

\section{3. 腎臓の構造}

腎臟は，高度に分化・組織化した複雑かつ精緻な 
構造を有する，外縁部である腎皮質は，血管に富 み，腎小体，近位尿細管が存在して腎機能の重要な 部分を担っており，より内側の腎髄質は血管にそし く，ヘンレの係蹄，集合管等を含む．腎臟は両腎合 わせて数百グラム程度の全体重の $1 \%$ にも満たない 比較的小さな臟器であるが，尿生成のために多量の 血液を受けており，腎血液量は心排出量の 20-25\% にも及ぶ。腎門から腎動脈，腎静脈，輸尿管が出入 りし，これらは核酸導入の経路として重要である [Fig. 1(A)].

腎機能はネフロンを最小機能単位とする。腎血管 は，腎動脈，輸入細動脈，糸球体，輸出細動脈，尿 細管周囲毛細血管，腎静脈へ，尿細管はボウマン囊 にはじまり，近位尿細管，遠位尿細管，集合管，輸 尿管へと流れ，両者は，腎小体とそれに続く尿細管 部分で接しており，それぞれ糸球体ろ過，尿細管再 吸収が行われ，併せて，血液量・組成の維持，老廃 物除去を担っている [Fig. 1(B)]。腎小体及び尿細 管部分はその機能的重要性から腎疾患との関連も深 く，核酸導入における重要な標的である，以下，腎 臓への核酸導入の観点から重要な構成物質について 整理する.

腎小体は糸球体及びボウマン囊からなる。糸球体 毛細血管壁は，血管側から内皮細胞，主にIV 型コ ラーゲンからなりろ過障壁の主役である基底膜，足 細胞及び近年同定された先天性ネフローゼ症候群の 原因遺伝子産物であるネフリンを含む糸球体上皮細
胞スリット膜の 3 層で構成されており，血液はこれ を通して加圧ろ過され，ろ液がボウマン囊内に入る [Fig. 1 (C)]。糸球体ろ過は分子量依存的な限外ろ 過であると同時に，基底膜内の負電荷を帯びたプロ テオグリカンの存在により電荷依存的であり，一般 的に負電荷を帯びた物質は透過し難いが，20 mer 程度の一本鎖オリゴヌクレオチド（分子量 6000 程 度) 23,24) 2 本鎖の siRNA（分子量 13000 程度）25-27) 静脈内投与後の尿中への排泄が報告されており，糸 球体からろ過される。また，血管側から糸球体構造 を支持する形でメサンギウム細胞が存在する．この 細胞はその増加及び IL-6 産生による IgA 腎症等の 糸球体腎炎との関連が知られ，核酸導入の重要な標 的である．基底膜より血管側に存在するため，血流 を介して比較的容易に核酸導入が可能であると考え られる。

尿細管は糸球体でろ過された物質の再吸収におけ る中心となる部位である。尿細管部分の毛細血管壁 は，内皮細胞，内皮細胞基底膜，尿細管細胞基底 膜，内腔側に刷子縁を有する尿細管細胞からなり [Fig. 1 (D)]，周囲の間質部分と併せて薬物誘発 性・感染性炎症の多発部位である。以上のように, 腎臟のネフロンは，基底膜により，血管，尿細管， 間質部分に分画されているため，核酸導入部位は投 与経路に強く依存すると考えられ，経腎動脈，経腎 静脈，経輸尿管投与，腎実質への直接注入等の腎臓 局所投与が主に検討されている. ${ }^{2)}$
A

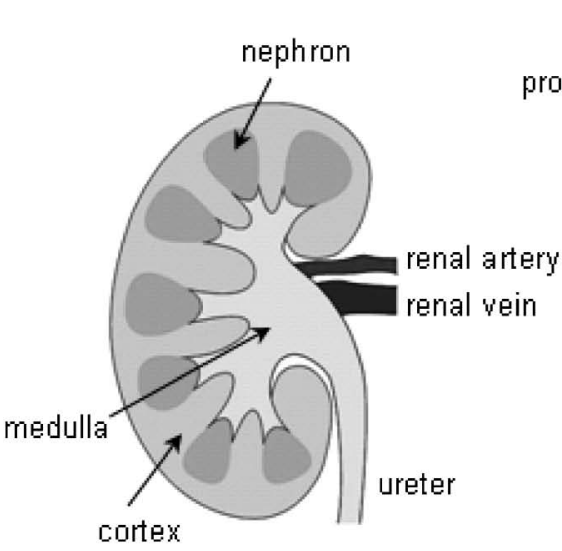

B

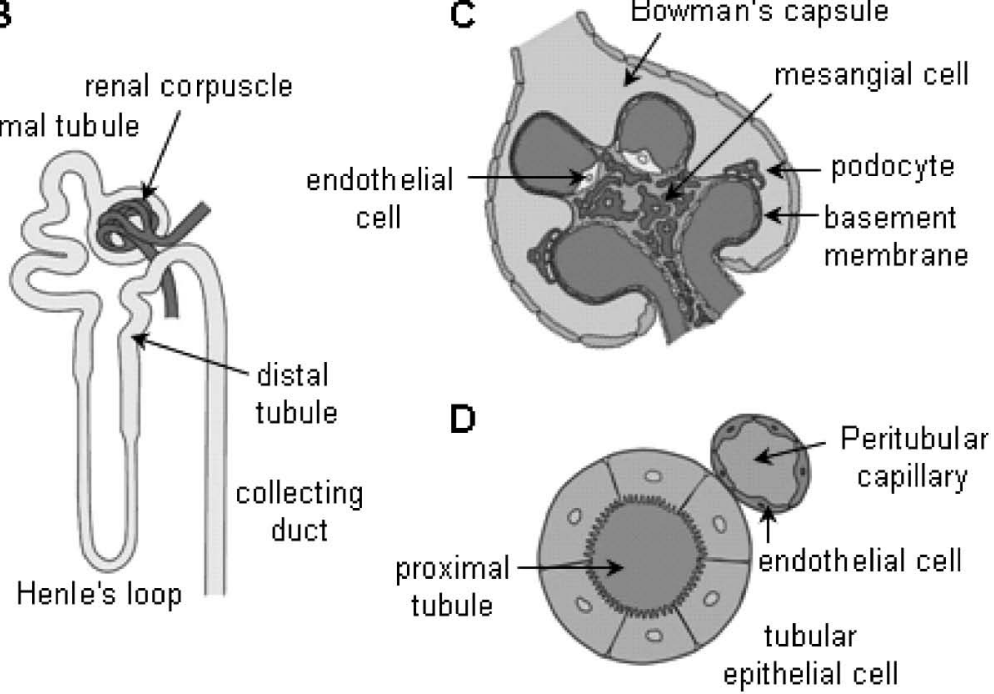

Fig. 1. Structure of the Kidney (A), Nephron (B), Renal Corpuscle (C) and Proximal Tubule (D) 


\section{4. リコンビナントウイルスによる腎臓への遺伝} 子導入

現在，遺伝子治療における臨床試験では，その導 入効率の高さから，治療遺伝子はウイルスベクター に組み込み, 自己増殖能を欠失したリコンビナント ウイルスとして投与することが多く，腎臓への遺伝 子導入に対しても適用が検討されている. リコンビ ナントウイルス全身投与による腎臓への選択的導入 は困難であり，経腎動脈，経腎静脈，経輸尿管投 与，腎実質への直接注入等の腎臓局所投与が試みら れている。一般的に，リコンビナントウイルスによ る遺伝子導入は，特異的抗体産生のため，先天性疾 患や慢性疾患において必要である複数回投与には適 さない.

4-1. リコンビナントアデノウイルスリコン ビナントアデノウイルス (Ad) は, coxsackie adenovirus receptors（CAR）を受容体とし，核膜孔を介 した核内移行機構を有するため，非分裂細胞を含む 幅広い細胞に対する高効率な感染を特長とし，現在 の遺伝子治療プロトコールにおいて最も多く利用さ れている。腎臓への遺伝子導入では 5 型 Ad を用い た検討が報告されている。腎臓は血流の多い臓器で あり，投与した Ad は速やかに全身循環を介し，肝 蔵や脾藏に取り込まれると考えられるため, 効率的 な遺伝子導入を達成するためには，Ad と腎臓細胞 との接触時間を長くする工夫が必要であり, 多様な 投与方法が検討されている.

Ad の経腎動脈投与による遺伝子導入では，ラッ トを用いた検討で，投与する腎臟の血流を一過性に 遮断し， Ad 注入後さらに数分一十分程度血流を遮 断し続ける方法が試みられ，尿細管上皮細胞への導 入が報告されている. ${ }^{11,28)}$ 一方で，ブタに対する腎 灌流法（2 時間灌流）を利用した遺伝子導入や, ${ }^{29)}$ ラット腎臓に対し経腎動脈的に 15 分間低速注入を 行った場合には, ${ }^{30)}$ 糸球体細胞へ効率的に導入され る。報告により導入部位が一致しないため，さらな る検討が必要である。他の投与経路では，腎孟投 与，腎実質への直接投与が検討されている．輸尿管 を結紮し，Ad を腎孟投与後，さらに，5分間尿路 を遮断し続けると髄質や腎乳頭の集合管細胞に導入

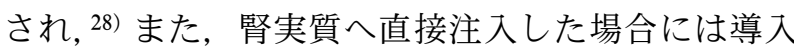
部位近傍のボウマン囊や尿細管上皮細胞，また，へ ンレループの太い上行脚部分に導入されると報告さ
れている. ${ }^{31,32)}$

4-2. リコンビナントアデノ随伴ウイルスリ コンビナントアデノ随伴ウイルス（AAV）は，ヒ 卜第 19 染色体（19q3.3）に組み込む性質を有する パルボウイルス科の一本鎖 DNA ウイルスの非増殖 性組み換え体であるが，治療遺伝子を挿入するため 組み込みに係わる rep 遺伝子を欠損させた AAV が 用いられることもあり，その場合は染色体に組み込 まれない，免疫原生が低く，病原性がない利点があ り，また，非分裂細胞に対しても遺伝子導入能があ り, 肝臓, 肺をはじめ多様な臟器への導入において アデノウイルスの代替として注目されている，5型 AAV はヒトやマウスの初代培養系を用いた検討で は，多様な腎臓細胞に対し同等の遺伝子導入効率を 示すにも係わらず，マウス腎実質への直接注入にお いて，導入部位近傍の尿細管上皮細胞に遺伝子発現 が限局されることが報告されている. ${ }^{33)} ま た ， 2$ 型 AAV をラット腎臓へ経腎動脈投与し，さらに，45 分間腎血流遮断した場合，同様に尿細管上皮細胞で の遺伝子発現が報告されているが，遺伝子導入され ている部位は，近位尿細管の S3 部分と集合管の間 在細胞に限られている. ${ }^{34)}$

4-3. リコンビナントレトロウイルス その 他，リコンビナントレトロウイルスは，免疫原生が 比較的低く，遺伝子の染色体挿入による高い発現持 続性が利点であるが，その挿入は非特異的であり， 発がんの危険性が懸念されている，腫瘍レトロウイ ルスは核内移行機構を持たず，分裂時の核膜消失期 にしか核内移行できないために，非分裂細胞に対し ては感染しない，基本的には腎臓細胞は分裂性に乏 しいため，腎臓への遺伝子導入への適用は不向きで あるが，葉酸腹腔内投与により，尿細管再生を促し たラットに対し，マウス白血病ウイルスを基にした リコンビナントレトロウイルスを腎実質へ直接注入 した場合，注入部位近傍の一部の尿細管上皮細胞に おいて発現がみられることが報告されている. ${ }^{35)} レ$ トロウイルスの一亜種であるレンチウイルスは，プ レインテグレーション複合体が核膜複合体を介して 核内移行可能であり，非分裂細胞に対しても遺伝子 導入が可能である.リコンビナントヒト免疫不全症 ウイルスの経腎動脈，経腎静脈，経輸尿管投与，腎 実質への直接注入によるマウス腎臟への遺伝子導入 検討が行われた。腎実質への直接注入や経輸尿管投 
与により，近位尿細管細胞等で遺伝子発現がみら れ，加えて， 3 力月以上の遺伝子発現持続が報告さ れている. ${ }^{36)}$

\section{5. 合成キャリアを利用した腎臓への核酸導入技} 術

治療遺伝子をプラスミドベクターに組み込み，合 成キャリアや物理刺激等を利用して遺伝子導入する 方法は，リコンビナントウイルスによる遺伝子導入 の場合に生じる，ウイルスに由来する免疫応答や特 異的抗体産生による複数回投与時の発現低下等の懸 念がないことが大きな利点である。これらの方法は 同時に有効なオリゴ核酸導入法としても注目される。

合成キャリアとして代表的なカチオン性リポソー ムやポリエチレンイミン（PEI）を用いた腎臓への 遺伝子導入が検討されており, $N$-[1-(2,3-dioleyloxy) propyl ] $-N, N, N$-trimethylammonium chloride ( DOTMA) / dioleoylphosphatidylethanolamine (DOPE) を脂質組成とするカチオン性リポソームとプラスミ ドベクター複合体の経腎動脈，経腎孟投与, ${ }^{37)}$ 及 び，側鎖構造を持つ分子量 $25 \mathrm{kDa}$ の PEI とプラス ミドベクター複合体の経腎動脈投与による, ${ }^{38)}$ 尿細 管上皮細胞への遺伝子導入が確認されている。また，

DOPE / dilauroylphosphatidylcholine / $N$ - ( $\alpha$-trimethylammonioacetyl ) -didodecyl-D-glutamate chloride を脂質組成とするマルチラメラ型リポソームとデコ イオリゴ核酸複合体の経腎動脈投与では，メサンギ ウム細胞へ導入されることが報告されている. ${ }^{18)}$ そ れぞれ，核酸複合体を注入後，血管，あるいは，尿 路を数分一十分結紮して腎臓細胞と接触させ，導入 効率を高めている.

一方で，LipofectAmine を用いたラット及びヒト 初代培養メサンギウム細胞への遺伝子導入実験にお いて高い細胞毒性が，ラット腎臓への in vivo 遺伝 子導入において血腫，出血，梗塞ネクローシスが報 告されており，腎毒性が懸念されている. ${ }^{39)}$ In vivo 核酸導入では，血球成分等の生体成分との相互作用 のため, ${ }^{40,41)}$ 脂質組成，電荷等の in vivo での最適 化が重要であるが，肺や肝臓等への核酸導入と比較 して報告例は非常に少なく，詳細な毒性に関する検 討もなされていないのが現状である.

また， hemagglutinating virus of Japan (HVJ) の膜融合を司る糖タンパク質 $\mathrm{HN}$ 及び $\mathrm{F}$ をアニオ ン性リポソーム脂質膜内に混在させた，リソソーム
分解を回避して効率的な核酸導入が期待される HVJ リポソームを利用した腎臓への核酸導入が検 討されている。プラスミドベクター内封 HVJ リポ ソーム経腎動脈投与による 15-40\%の糸球体細胞で の遺伝子発現, ${ }^{42,43)}$ また, HIV エンベロープ脂質組 成を模倣した HVJ リポソーム経輸尿管投与によ る，尿細管間質線維芽細胞への導入が報告されてい る. ${ }^{44)}$

\section{6. 物理刺激を利用した腎臓への核酸導入技術}

物理刺激を利用しプラスミドベクター並びにオリ ゴ核酸の細胞内移行効率を向上させる戦略は，一過 性の細胞膜透過性六進を導入機構とするため，上記 のリコンビナントウイルスや合成キャリアを用いた 核酸導入において要求される長期間に亘る血管や尿 路の遮断が不要であり，また，虚血再灌流時炎症に 伴う組織傷害の懸念がなく，腎臓への核酸導入にお いて特に有効な戦略であると考えられる.

一般的に，負電荷を帯び高分子量であるプラスミ ドベクター水溶液単独投与では遺伝子導入は達成さ れないが，大容量の水溶液を尾静脈から急速注入す ることによって肝臓で高い発現が得られることが示 されている. ${ }^{45)} こ の$ 戦略を腎臟への遺伝子導入に適 用した例として，ラットを用い，腎動脈，腎静脈を クランプしたのち，腎藏容積に匹敵する $1 \mathrm{ml}$ のプ ラスミドベクター水溶液を 5 秒以内に経腎静脈投与 することで尿細管周囲毛細血管網近傍の間質線維芽 細胞において遺伝子発現が得られることが報告され ている. ${ }^{46)}$ 一方，静脈内投与されたオリゴ核酸は, 糸球体ろ過されたのち，一部は Scavenger 受容体が 関与したエンドサイトーシス等により，近位尿細管 細胞に導入されることが示されている. ${ }^{23,24,47)}$

\section{6-1. エレクトロポレーション法エレクトロ} ポレーション法は，強力な電場パルスを細胞や臓 器，組織に与え，細胞膜透過性を一過性に元進，導 入効率を向上させる核酸導入法であり，既に，筋肉 をはじめ様々な臓器, 組織に対して適用されてい る。ラットを用いた検討で，腎動脈，腎静脈を結禁 した上で，プラスミドベクター水溶液を経腎動脈投 与し，腎臓に対し電場パルス照射すると， $75 \%$ の糸 球体メサンギウム細胞に遺伝子導入された. ${ }^{48)}$ 同様 の方法は siRNA 導入に対しても効果的であり，95 \%以上の糸球体細胞で遺伝子発現抑制効果を示し, 特に，メサンギウム細胞で顕著であると報告されて 


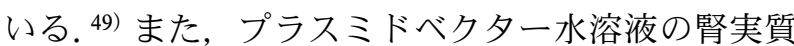
直接投与, ${ }^{50)}$ 及び， DNA enzyme 水溶液の経腎静脈 投与51)によるエレクトロポレーション法において， 尿細管間質線維芽細胞への核酸導入が確認されてい る.

6-2. ソノポレーション法超音波診断用造影 剂であるマイクロバブルに超音波照射すると，マイ クロバブルが核になり効果的にキャビテーションが 誘導でき，培養細胞や筋肉内投与において高効率な 核酸導入が可能である。エレクトロポレーション法 の場合と同様にラット腎動脈，腎静脈を結紮した上 で，プラスミドベクターと造影剤 Optison 混合溶液 を経腎動脈投与し，腎蔵に超音波照射すると 70-80 \%以上の糸球体細胞，加えて，尿細管や間質領域で 遺伝子発現が認められた. ${ }^{52,53)}$ デコイ DNA 導入に

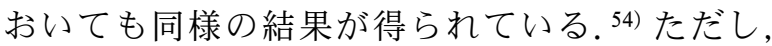

Optison 高濃度条件では, 細胞外マトリックス拡
張，糸球体径増加等の糸球体組織学的傷害がみら れ，安全な核酸導入のためには Optison 濃度最適化 が必要であることが示唆されている. ${ }^{53}$

\section{6-3. Renal press-mediated transfection method}

最近，われわれは，新規な物理刺激を利用した腎 臓への核酸導入法として，renal press-mediated transfection method を報告している. ${ }^{55)}$ 本方法は, 核酸溶液をマウス尾静脈から注入したのち，腎臓に 軽く 1 秒間，圧（プレス）を加えるだけの非常に単 純で簡便な方法である [Fig. 2(A)]。レポーター遺 伝子としてルシフェラーゼ発現プラスミドベクター （pCMV-Luc）を用い評価すると，その遺伝子発現 は全身投与にも係わらず腎臓特異的であり [Fig. 2 (B) ]，腎臓における遺伝子導入効率（約 $4 \mathrm{ng} / \mathrm{mg}$ protein）は，リコンビナントアデノウイルス静脈 内投与による肝臓，脾蔵での遺伝子発現（1-30 ng/ mg protein) や, リポプレックスやポリプレックス
A

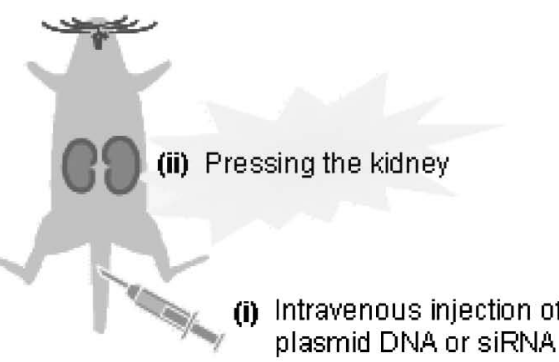

B

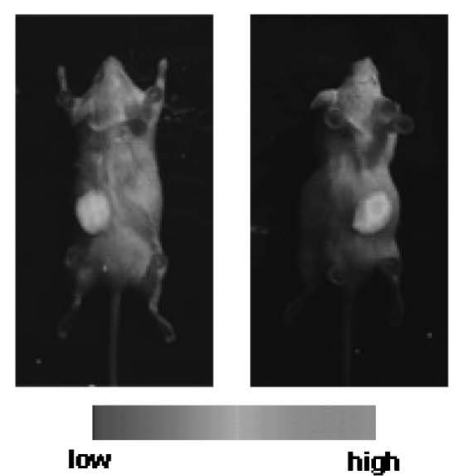

E
C

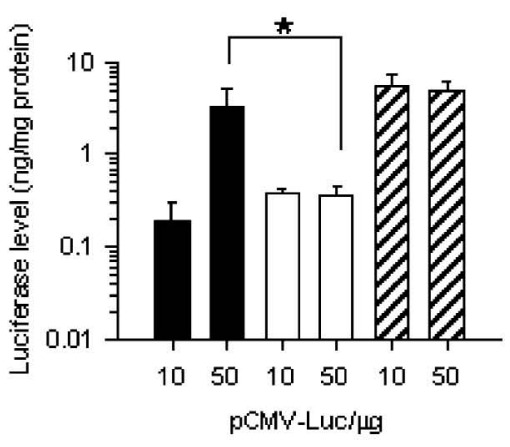

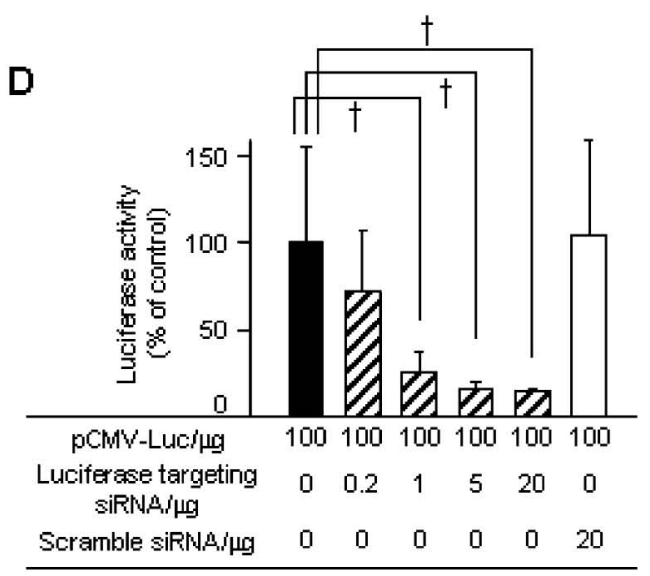
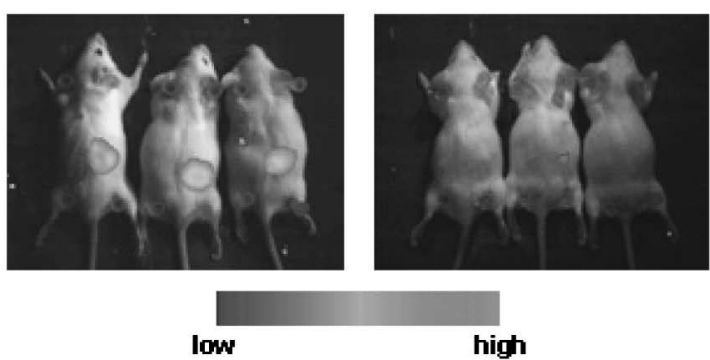

high

Fig. 2. Renal Press-mediated Transfection Method

(A) : Scheme of renal press-mediated transfection method procedure. (B) : In vivo imaging $12 \mathrm{~h}$ after $100 \mu \mathrm{g}$ pCMV-Luc administration to the right (right picture) or left (left picture) kidney. (C): Luciferase levels obtained by the renal press-mediated transfection method (black) were compared with renal parenchymal injection (white) and electroporation (hatched). (D): Luciferase levels $12 \mathrm{~h}$ after co-administration with pCMV-Luc and luciferase targeting siRNA or scramble siRNA, normalized by only pCMV-Luc administration. (E) : In vivo imaging $12 \mathrm{~h}$ after administration of $100 \mu \mathrm{g}$ pCMV-Luc (left picture) and co-administration of $100 \mu \mathrm{g} \mathrm{pCMV}-$ Luc and $5 \mu \mathrm{g}$ luciferase targeting siRNA (right picture) . ${ }^{*} p<0.01 .{ }^{*} p<0.05$. Each value represents means + S.D. (Reprinted from Ref. 55 ) with permission of Elsevier). 
による肺での遺伝子発現 $(0.1-1 \mathrm{ng} / \mathrm{mg}$ protein）に 匹敵し，腎実質への直接注入を用いたエレクトロポ レーション法と比較しても同程度 [Fig. 2(C) ] と 高効率である，加えて，血流を介しているため，皮 質, 髄質外帯領域など広範囲に遺伝子導入される。

またルシフェラーゼを標的とした siRNA を pCMV-Luc と同時投与すると, siRNA 投与量依存 的な遺伝子発現抑制がみられ，本方法は腎臟への siRNA 導入に対しても適用可能である [Fig. 2(D)， (E) ]。さらに，クレアチニン並びに血中尿素窒素 を腎機能の指標として，本方法の腎機能に及ぼす影 響について経時的に評価したところ，非処置群と比 較し，変化はみられず，顕著な腎毒性は引き起こさ れないことが示唆された。 Renal press-mediated transfection method は単純な戦略で，しかも，顕 著な腎機能低下を引き起こすことなく，腎臟特異的 に高効率かつ広範囲に核酸導入可能であることか ら, 臨床応用実現へ向けた今後の研究推進が期待さ れる，通常，腎臓への核酸導入を利用した実験では ラットの使用が必要となるが，本方法を用いる場 合，簡便に小動物であるマウスを使った実験が可能 であり，迅速な個体レベルでの遺伝子機能解析，疾 患モデル構築，遺伝子治療・核酸医薬品開発の戦略 検証等が可能になると考えられる.

\section{7. 腎がん組織への直接注入}

腎がんに対しては，コンピューティッド・トモグ ラフィー（CT）ガイド下穿刺等による，腎がん組 織への遺伝子発現ベクター直接注入を利用した遺伝 子治療臨床試験が進められており，HLA-B7ゃ IL-2 の遺伝子発現プラスミドベクターリポソーム 製剂である Allovectin 756) と Leuvectin ${ }^{57)}$ が代表的 である。これらリポソーム製剤は，1,2-dimyristyloxypropyl-3-dimethyl-hydroxy ethyl ammonium bromide (DMRIE) /DOPE の脂質組成からなるカチ才 ン性リポソームとプラスミドベクターの複合体であ る。リコンビナントアデノウイルス（Ad）を利用 した遺伝子導入も検討されているが，腎細胞がんに おいてアデノウイルスの受容体である CAR の発現 は低いとされており，高発現が報告されている $\alpha \mathrm{V}$ インテグリンを標的とした組み換え Adによる遺伝 子導入が有効ではないかと推察されている. ${ }^{58)}$

\section{8. おわりに}

本稿では腎疾患に対する遺伝子治療，核酸医薬品
において治療効果を左右し得る動態学的要因につい て重点的に論述した。近年，遺伝子治療，核酸医薬 品開発において土台となる導入技術に関する情報が 蓄積されつつあり，さらなる各腎疾患に対する核酸 導入システムの最適化により，将来の腎疾患に対す る遺伝子治療，核酸医薬品実現につながるものと期 待している。

謝辞 有益な御助言及び多大な御支援を賜りま した京都大学大学院薬学研究科山下富義准教授，ま た，実験に御協力頂きました大学院生，馬 凡，高 橋晴之，大谷祐基さんに深謝致します。最後に，薬 学会大学院生シンポジウム, 並びに, 薬学雑誌誌上 シンポジウムにおける発表の機会を与えて頂きまし た薬学会関係者の皆様に改めて感謝の意を表します。

\section{REFERENCES}

1) Knebelmann B., Antignac C., Gubler M. C., Grunfeld J. P., Kidney Int., 44, 1205-1216 (1993)

2) Kelley V. R., Sukhatme V. P., Am. J. Physiol. Ren. Physiol., 276, F1-F9 (1999).

3) Yamada M., Katsuma S., Adachi T., Hirasawa A., Shiojima S., Kadowaki T., Okuno Y., Koshimizu T. A., Fujii S., Sekiya Y., Miyamoto Y., Tamura M., Yumura W., Nihei H., Kobayashi M., Tsujimoto G., Proc. Natl. Acad. Sci. U. S. A., 102, 7736-7741 (2005).

4) Mahato R. I., Takakura Y., Hashida M., J. Drug Target., 4, 337-357 (1997).

5) Mahato R. I., Takakura Y., Hashida M., Crit. Rev. Ther. Drug Carrier Syst., 14, 133-172 (1997).

6) Kawakami S., Higuchi Y., Hashida M., $J$. Pharm. Sci., 97, 726-745 (2008).

7) 〈http://www4.od.nih.gov/oba/rac/PROTOCOL.pdf $\rangle$, Office of Biotechnology Activities, U. S. National Institutes of Health Web, 5 June, 2008.

8) 〈http://clinicaltrials.gov/ , U. S. National Institutes of Health Web, 1 April, 2008.

9) Heikkila P., Tibell A., Morita T., Chen Y., Wu G., Sado Y., Ninomiya Y., Pettersson E., Tryggvason K., Gene Ther., 8, 882-890 (2001).

10) Tomita N., Morishita R., Tomita S., Gibbons 
G. H., Zhang L., Horiuchi M., Kaneda Y., Higaki J., Ogihara T., Dzau V. J., Gene Ther., 7, 1326-1332 (2000).

11) Takase O., Hirahashi J., Takayanagi A., Chikaraishi A., Marumo T., Ozawa Y., Hayashi M., Shimizu N., Saruta T., Kidney Int., 63, 501-513 (2003).

12) Matsumoto K., Nakamura T., Kidney Int., 59, 2023-2038 (2001).

13) Gao X. J., Mae H., Ayabe N., Takai T., Oshima K., Hattori M., Ueki T., Fujimoto J., Tanizawa T., Kidney Int., 62, 1238-1248 (2002)

14) Akagi Y., Isaka Y., Arai M., Kaneko T., Takenaka M., Moriyama T., Kaneda Y., Ando A., Orita Y., Kamada T., Ueda N., Imai E., Kidney Int., 50, 148-155 (1996).

15) Isaka Y., Tsujie M., Ando Y., Nakamura H., Kaneda Y., Imai E., Hori M., Kidney Int., 58 1885-1892 (2000).

16) Terada Y., Hanada S., Nakao A., Kuwahara M., Sasaki S., Marumo F., Kidney Int., 61, S94-S98 (2002).

17) Lan H. Y., Mu W., Tomita N., Huang X. R., Li J. H., Zhu H. J., Morishita R., Johnson R. J., J. Am. Soc. Nephrol., 14, 1535-1548 (2003).

18) Maeshima Y., Kashihara N., Yasuda T., Sugiyama H., Sekikawa T., Okamoto K., Kanao K., Watanabe Y., Kanwar Y. S., Makino H., J. Clin. Invest., 101, 2589-2597 (1998).

19) Carl M., Akagi Y., Weidner S., Isaka Y., Imai E., Rupprecht H. D., Kidney Int., 63, 13021312 (2003).

20) Rini B. I., Small E. J., J. Clin. Oncol., 23, 1028-1043 (2005).

21) Lin J. M., Lalani A. S., Harding T. C., Gonzalez M., Wu W. W., Luan B., Tu G. H., Koprivnikar K., VanRoey M. J., He Y. L., Alitalo K., Jooss K., Cancer Res., 65, 69016909 (2005).

22) Jain R. K., Duda D. G., Clark J. W., Loeffler J. S., Nat. Clin. Pract. Oncol., 3, 24-40 (2006).

23) Rappaport J., Hanss B., Kopp J. B., Copeland T. D., Bruggeman L. A., Coffman T. M., Klotman P. E., Kidney Int., 47, 14621469 (1995).

24) Oberbauer R., Schreiner G. F., Meyer T. W.,
Kidney Int., 48, 1226-1232 (1995).

25) van de Water F. M., Boerman O. C., Wouterse A. C., Peters J. G. P., Russel F. G. M., Masereeuw R., Drug Metab. Dispos., 34, 1393-1397 (2006).

26) Sato A., Takagi M., Shimamoto A., Kawakami S., Hashida M., Biomaterials, 28, 14341442 (2007).

27) Kawakami S., Hashida M., Drug Metab. Pharmacokinet., 22, 142-151 (2007).

28) Moullier P., Friedlander G., Calise D., Ronco P., Perricaudet M., Ferry N., Kidney Int., 45, 1220-1225 (1994).

29) Heikkila P., Parpala T., Lukkarinen O., Weber M., Tryggvason K., Gene Ther., 3, 21-27 (1996)

30) Ye X. H., Liu X. H., Li Z. W., Ray P. E., Human Gene Ther., 12, 141-148 (2001).

31) Choi Y. K., Kim Y. J., Park H. S., Choi K., Paik S. G., Lee Y. I., Park J. G., Gene Ther., 10, 559-568 (2003).

32) Ortiz P. A., Hong N. J., Plato C. F., Varela M., Garvin J. L., Kidney Int., 63, 1141-1149 (2003)

33) Lipkowitz M. S., Hanss B., Tulchin N., Wilson P. D., Langer J. C., Ross M. D., Kurtzman G. J., Klotman P. E., Klotman M. E., J. Am. Soc. Nephrol., 10, 1908-1915 (1999).

34) Chen S. F., Agarwal A., Glushakova O. Y., Jorgensen M. S., Salgar S. K., Poirier A., Flotte T. R., Croker B. P., Madsen K. M., Atkinson M. A., Hauswirth W. W., Berns K. I., Tisher C. C., J. Am. Soc. Nephrol., 14, 947958 (2003).

35) Bosch R. J., Woolf A. S., Fine L. G., Exp. Nephrol., 1, 49-54 (1993).

36) Gusella G. L., Fedorova E., Hanss B., Marras D., Klotman M. E., Klotman P. E., Human Gene Ther., 13, 407-414 (2002).

37) Lai L. W., Moeckel G. W., Lien Y. H. H., Gene Ther., 426-431 (1997).

38) Boletta A., Benigni A., Lutz J., Remuzzi G., Soria M. R., Monaco L., Human Gene Ther. 8, 1243-1251 (1997).

39) Madry H., Reszka R., Bohlender J., Wagner J., J. Mol. Med., 79, 184-189 (2001).

40) Fumoto S., Kawakami S., Shigeta K., Higuchi Y., Yamashita F., Hashida M., J. Pharmacol. Exp. Ther., 315, 484-493 (2005). 
41) Hohokabe M., Higuchi Y., Mukai H., Kawakami S., Hashida M., J. Biomed. Nanotech., 3, 277-284 (2007).

42) Tomita N., Higaki J., Morishita R., Kato K., Mikami H., Kaneda Y., Ogihara T., Biochem. Biophys. Res. Comm., 186, 129-134 (1992) .

43) Isaka Y., Fujiwara Y., Ueda N., Kaneda Y., Kamada T., Imai E., J. Clin. Invest., 92, 2597-2601 (1993).

44) Tsujie M., Isaka Y., Ando Y., Akagi Y., Kaneda Y., Ueda N., Imai E., Hori M., Kidney Int., 57, 1973-1980 (2000).

45) Liu F., Song Y. K., Liu D., Gene Ther., 6, 1258-1266 (1999).

46) Maruyama H., Higuchi N., Nishikawa Y., Hirahara H., Iino N., Kameda S., Kawachi H., Yaoita E., Gejyo F., Miyazaki J. I., Human Gene Ther., 13, 455-468 (2002).

47) Sawai K., Mahato R. I., Oka Y., Takakura Y., Hashida M., J. Pharmacol. Exp. Ther., 279, 284-290 (1996).

48) Tsujie M., Isaka Y., Nakamura H., Imai E., Hori M., J. Am. Soc. Nephrol., 12, 949-954 (2001).

49) Takabatake Y., Isaka Y., Mizui M., Kawachi H., Shimizu F., Ito T., Hori M., Imai E., Gene Ther., 12, 965-973 (2005).

50) Fujii N., Isaka Y., Takabatake Y., Mizui M., Suzuki C., Takahara S., Ito T., Imai E., Nephrol. Dial. Transplant., 21, 2745-2753 (2006)
51) Nakamura H., Isaka Y., Tsujie M., Rupprecht H. D., Akagi Y., Ueda N., Imai E., Hori M., Gene Ther., 9, 495-502 (2002).

52) Lan H. Y., Mu W., Tomita N., Huang X. R., Li J. H., Zhu H. J., Morishita R., Johnson R. J., J. Am. Soc. Nephrol., 14, 1535-1548 (2003)

53) Koike H., Tomita N., Azuma H., Taniyama Y., Yamasaki K., Kunugiza Y., Tachibana K., Ogihara T., Morishita R., J. Gene Med., 7, 108-116 (2005).

54) Azuma H., Tomita N., Kaneda Y., Koike H., Ogihara T., Katsuoka Y., Morishita R., Gene Ther., 10, 415-425 (2003).

55) Mukai H., Kawakami S., Hashida M., Biochem. Biophys. Res. Commun., 372, 383387 (2008).

56) Rini B. I., Selk L. M., Vogelzang N. J., Clin. Cancer Res., 5, 2766-2772 (1999).

57) Galanis E., Hersh E. M., Stopeck A. T., Gonzalez R., Burch P., Spier C., Akporiaye E. T., Rinehart J. J., Edmonson J., Sobol R. E., Forscher C., Sondak V. K., Lewis B. D., Unger E. C., O’Driscoll M., Selk L., Rubin J., J. Clin. Oncol., 17, 3313-3323 (1999).

58) Haviv Y. S., Blackwell J. L., Kanerva A., Nagi P., Krasnykh V., Dmitriev I., Wang M. H., Naito S., Lei X. S., Hemminki A., Carey D., Curiel D. T., Cancer Res., 62, 4273-4281 (2002). 